\title{
EFFECTS OF SYNTHETIC AGRICULTURAL CHEMICALS ON HEALTH: VIEWS OF SMALLHOLDER FARMERS IN THE HO WEST DISTRICT
}

\author{
K.F. Egbadzor ${ }^{1}$ and E.K. Sakyi ${ }^{2}$ \\ ${ }^{I}$ Department of Agro Enterprise Development, Ho Technical University, Ho, Ghana. \\ kegbadzor@htu.edu.gh \\ ${ }^{2}$ University of Ghana Business School, Legon, Accra, Ghana \\ KSakyi@ug.edu.gh
}

\begin{abstract}
The use of agro-chemicals especially insecticides and herbicides has become a very common agricultural practice among smallholder farmers in Ghana including the Ho West District of the Volta Region. The worrying issue is the inappropriate application of these chemicals. This study explored smallholder farmers' knowledge of the adverse effects of the application of agrochemicals on crops, animals and human health. This was a qualitative study and data were collected using focus groups of smallholder farmers from the Ho West District. The groups were purposively selected with the aim of capturing farmers who are knowledgeable in the use of agro-chemicals. Five group interviews consisting of six (6) to twelve (12) farmers in each group were organised. The findings suggested that although, many of the farmers are aware of the harmful effects of the chemicals on crops, animal, humans and the environment, they do not wear personal protective equipment during application. Overwhelming majority of the interviewees do not use safety clothing such as gloves, nose-covering, hand-washing and eye protection gadgets. Seventy percent of the farmers reported that they never had any training regarding the use of these chemicals, and that radio advertisements are the main source of their information regarding usage. Encouragingly, all of them admitted that they are ready and willing to avail themselves to learn and acquire skills needed for effective application of these chemicals. As agro-chemicals have become indispensable in modern day farming, it is imperative for government and other stakeholders to provide training opportunities for farmers on proper handling of the chemicals so that lives and the environment are protected.
\end{abstract}

Key Words: Environment, focus group, herbicides, insecticides, living organisms https://dx.doi.org/10.4314/jafs.v18i2.5

\section{INTRODUCTION}

Agriculture is the backbone of Ghana's economy similar to that of many African countries (Diao et al., 2010). Although, the rate of development in the agricultural sector is slow, it will remain fundamental and inseparable from economic liberation agenda pursued in the country. Even with the commercial production of oil, agriculture still remains the foundation upon which Ghana's economic survival depends. This is evident from the fact that majority of the population derive Journal of the Faculty of Agriculture and Veterinary Medicine, Imo State University Owerri website: www ajol.info; Attribution: Non-commercial CC BY-NC 
their livelihood from the agriculture sector. The agricultural sector contributes $22 \%$ to Ghana's GDP against $28.6 \%$ and $49.5 \%$ respectively for the industrial and the services sectors (GSS, 2010).

The agricultural sector is dominated by smallholder farmers who combine the cultivation of cash crops such as cocoa and coffee with food crops like legumes, cereals and root and tuber crops. Crop yields are low due to a number of factors including infertile soils, degradation of farmlands through bad farming practices and the menace of illegal mining (Aragon and Rud 2011; Franke et al., 2019; Lobell et al., 2009). These factors directly and indirectly have contributed to farmers' extensive use of synthetic agro-chemicals (Omari, 2014). Some farmers also adopted strategies such as irrigation and the use of disease and pest resistant varieties to increase yields as response to the challenges confronting them (Mabe et. al., 2017). Other farmers on the other hand resort to the extensive use of synthetic insecticides to increase yields. The heavy application of synthetic insecticides in particular is due largely to the emergence of new diseases and pests especially the recent invasion of farms by vicious fall army worms (FAW) (Spodoptera frugiperda). FAW has made the use of agro-chemicals a necessity rather than an option.

In respond to the FAW, government-initiated policies that have also in ways encouraged a phenomenal increase in the usage of agro-chemicals to control and curb the devastating effect of these insect pest (Okoffo et al., 2016). In this regard smallholder farmers are more than ever before invigorated to use agro-chemicals as the best available option to protect their crops and increase their productivity. This has led not only to an increase chemical use but also an indiscriminate application of synthetic agro-chemicals aimed at boosting production, controlling pest, weed, and disease on their farms. However, over reliance on agro-chemicals would result in unsustainable crop production (Fernie and Yan, 2019).

Any chemical that is used in agricultural production to improve productivity and control of pest and diseases qualifies as agro-chemical (Omari, 2014; Mabe et al. 2017). Ghanaian smallholder farmers have long used agro-chemicals, what is new in the current situation is the varieties and the intensity of usage without the requisite knowledge and guide. The use of agro-chemicals, particularly fertilizers, insecticides and pesticides will continue to be a fundamental part in the Ghanaian agricultural sector. For instance, Dinham (2003) in a study found that about $87 \%$ of vegetable farmers use chemical pesticides to control pests and diseases. Mabe et al., (2017) also noted that the use of agrochemicals is inseparable from contemporary farming activities in Ghana. What is critical is how the use of agricultural chemicals are controlled.

It is on record that runoff from agro-chemicals contaminate food crops and even spread to affect water bodies (Kuranchie-Mensah et al., 2012). According to Mabe et al. (2017) this problem is worsened by farmers usually out of ignorance wash their knapsack sprayers, equipment and their clothes in water bodies after spraying. However, many Ghanaians in both urban and rural communities depend on natural lakes, streams, and rivers as sources of drinking water. Studies have confirmed the presence of deposits of both banned chemicals and pesticides such as 
organochlorines and organophosphates in terrestrial food and aquatic environments in Ghana (Bempah and Donkor, 2011). Agro-chemicals of various kinds have contributed to the loss of animal and human lives, all due to ignorance and wrongful application (Northern Presbyterian Agricultural Services, 2012).

The benefits of using agro-chemicals are the driving force for a growing number of farmers to be embracing them day in day out (Lema et al., 2014). However, the consequences of their application can be devastating (Aktar et al., 2009). The misapplication of agro-chemicals in the district is similar to what is found elsewhere in the country (Kwakye et al., 2018). Even though the applications of synthetic agro-chemicals have become common among farmers in Ghana, the required knowledge by farmers for their applications remain a fairy-tale. It was in the light of this situations that the present study was conducted in the Ho West District, Volta Region, Ghana to verify from farmers the importance of agro-chemicals to them, if they had training on the application of agro-chemicals and if they use personal protective equipment. In addition, the study pursued from the farmers, their perception on the effect of agro-chemicals on crops, human beings and the environment.

\section{METHODOLOGY}

\section{The Study Area}

Ho West District is located between latitudes 6.33 $32^{\circ}$ " $\mathrm{N}$ and $6.93^{\circ} 63^{\prime \prime} \mathrm{N}$ and longitudes $0.17^{\circ}$ $45^{\prime \prime}$ E and $0.53^{\circ} 39^{\prime \prime}$ E. It shares boundary with the Ho Municipality to the South, the South Dayi to the North West and the Afadzato South to the North East. It also stretches to its South Eastern boundary with the Adaklu and the North Tongu Districts. According to the Housing and Population Census of Ghana in 2010, the District had a population of 94,600 comprising of $48 \%$ and 52\% males and females respectively (Ghana Statistical Service 2014). Ho West is mostly rural with $88.7 \%$ of the people farmers. The soil and climatic conditions in addition to the predominant rural nature of the district make it favourable for agricultural activities of which crop farming accounts for $95.0 \%$. The land is also favourable for large scale cash crops production especially oil palm, mango, coffee and cocoa, hence the establishment of Seed Production Division of Ghana's Cocoa Marketing Board (COCOBOD) at Saviefe Agokpo. Other crops that are grown include food crops such as cereals particularly maize and rice; root and tubers including yam and cassava; legumes mainly cowpea and groundnut and a range of vegetables.

Focus group discussions were conducted with five purposively farmer groups. The selected farmer groups for the study were based on their vibrancy in major agricultural activities as confirmed by the office of the Ministry of Food and Agriculture (MoFA). These groups are wellorganized in such a way that meeting and interacting with them was very easy. The groups also cultivate a wide range of crops representing agronomic activities that are predominant in the district. 
The groups were identified with the help of the Agricultural Extension Agents (AEAs) of MoFA. The number of focus group discussant was planned to be six. However, the day coincided with other group activities at HolutaTogorme and AwudomeAvenui hence their number as 10 and 12 respectively. The farmer groups are shown in Table 1.

The AEA informed the farmers in advance of the meeting. On the scheduled day, the farmers of the particular group met at one place for the focus group interview. The research team including the AEA used interview guide in obtaining information from the farmers relating to their training, effect of the chemicals on crops, animals, themselves and the environment. Notes were taken on the interaction. A mix of quantitative (descriptive statistics) and qualitative techniques were used in the analysis and interpretation of data.

\section{RESULTS AND DISCUSSION \\ Sociodemographic characteristics of smallholder farmers}

There were uniqueness and commonalities among the five farmer groups used for the study. The target number of focus group members for each association was six. Number of members of the farmer groups however, as stated by discussants were thirty and above. Men dominated all the groups both as members and for the focus group discussion. One woman each was involved in Dzolo Gbogame, Awudome Anyirawase and Saviefe Gbedome. No woman was involved in Holuta Togorme and Awudome Avenui (Table 1). All the forty participants were married with varying number of children.

Crops cultivated vary within and between farmer groups. However, each farmer cultivates multiple crops. Member of Dzolo Gbogame and Awudome Anyirawase farmer groups have rice in common. Holuta and Awudome Avenui farmers have cocoa while Saviefe Gbedome farmers have diverse crops within the group including maize, yam, cassava, cowpea and groundnut. This diversity in crops help to have a broad response on the use of agro chemicals. Saviefe Gbedome is a settler community comprising of farmers with origin from different towns. They cultivate mainly maize, rice, cassava, yam, groundnut, cowpea, vegetables and pineapple. Only few domestic animals such as local chicken and goats and sheep are found in the communities.

The mean age of farmers of the various groups varied from 48 for Saviefe to 74 for Avenui as shown in the table. Age uniformity also varied among the farmer groups. Apart from one farmer who was 38 years old, all the farmers of Dzolo Gbogame were in their fifties. Age of farmers of Awudome Anyirawase varied from 45 to 60 with the average of 52. Those of Saviefe Gbedome and Holuta Togorme had wide variation, between thirty and seventy. Most of the group member of AwudomeAvenui were above seventy years of age with the average of 74 . 
Major findings of the study are summarised in Table 1. The response of all the five farmer groups were similar except for the training on agro-chemicals. For training on agro-chemicals, two farmer groups responded that they had training while three responded no. For the other five questions, all the farmer groups responded positively to three and negatively to two.

\section{Importance of agro-chemicals}

The use of agro-chemicals especially herbicides, insecticides and fertilisers have become indispensable in crop production in the study areas similar to the report of Mabe et al., (2017). Every single member of the focus groups confirmed that they use them and that their use will continue in their farming activities. Farmers of these communities believe that it will be daunting to farm currently without agro-chemicals especially herbicides, fertilisers and insecticides. "We cannot farm without agro-chemicals today", said by the leader at Dzolo. Some other responses to the question of importance of agro-chemicals were stated as follows;

"agro-chemicals are helping us a lot" "agro-chemicals are very important to us" "they are so important" "the more chemicals you can buy the bigger you can farm".

According to all of the farmers in the study, the use of herbicides is cheaper than labour in weed control. Both capital and labour costs are reduced with the application of herbicides compared with manual weeding (Shrestha et al., 2013). In the case of insecticides, farmers lamented that crop yields are highly reduced if they are not applied due to insect pests' damage. It is therefore, not economical to cultivate most crops without the use of insecticides. The claims of pests' damage might be true to some extent, however, integrated management with reduced application of insecticides can increase natural enemies' population and also improve environmental quality (Alli et al., 2017). The presence or damage of a pest to a crop may also not necessarily mean economic loss (Macfadyen et al., 2014). Technical assistance is therefore needed to be provided to farmers on the appropriate application of agro-chemicals including insecticides.

Most of the new crop varieties being grown require fertilisers for optimum yields. Farmers in the study area embrace the new crop varieties with the recommended cultural practices therefore, cannot do away with chemical fertilisers. Farmers at Holuta Togorme talked of the degrading land necessitating the use of fertilisers and the mountainous nature of their lands cannot allow the use of tractors so heavily dependent on herbicides. Farmers in Ho West District therefore, attached importance to the use of agro-chemicals especially herbicides, insecticides and fertilisers in crop farming.

\section{Training on the use of agro-chemicals}

Responses on training on agro-chemicals varied from one farmer group to the other. Similar to farmers learning farming business from their parents and community members, they also learnt the use of agro chemicals mostly from other farmers in their communities. Member of Dzolo 
Gbogame Nyuiemedzi and Awudome Anyirawase Lorlornyo Rice Farmers Associations stated that they were trained by some Agricultural Extension Agents in the past on the use of agrochemicals. These two farmer groups also have rice cultivation as the common crop. The training they talked about might be for rice farmers. However, they said that they will welcome further training.

According to Dzolo Gbogame Nyuiemedzi farmers, they were trained but call for general public training for all farmers in the area. The Dzolo group is quite knowledgeable in farming which again could be attributed to regular visits by Agricultural Extension Agents. Holuta Togorme group is also quite knowledgeable in farming similar to Dzolo group. However, they had no organised training on the use of agro-chemicals. They, asked for more trainings to include agrochemicals handling and in other crops apart from cocoa for which the agents normally visit them. According to the leader of Holuta, "we need the agricultural experts to give us training on the new chemicals".

In addition to Holuta Togorme Farmers' Association, Saviefe Gbedome and Awudome Avenui Balime Cocoa Farmers Associations stated that they did not have any organised training in the use of agro-chemicals. This could lead to misapplication as stated by Kwakye et al. (2018). These farmers normally hear of different agro chemicals on radio advertisement. They also learn from other community members. They call for training from the Agricultural Extension Agents.

\section{Use of protective clothing}

Members of all the farmer groups involved in the study are aware of the benefits of using protective clothing. However, they do not normally use them. Poor clothing such as wearing of knickers, bare foot and short sleeves is common among farmers in the area. Majority of farmers (70\%) do not use nose and mouth guards, hand gloves and overall. These farmers therefore, do not put on standard personal protective clothing (Ogget al., 2018). At Saviefe Gbedome, the use of protective clothing is non-existence, their women use long dresses without trousers and wellington boot when spraying agro chemicals. The use of wellington boots is high in some communities like Awudome Anyirawase and Dzolo Gbogame. Both male and female farmers at Anyirawase use trousers and wellington boots during chemical application. According to the group (Anyirawase) they have had trainings in appropriate use of agro-chemicals. Protective materials that are less used in the study communities are goggles and mouth and nose guards. According to the farmers, they are not comfortable when they ware nose, eye and mouth protecting materials. Their problem with the use of nose and mouth guards is because of the inferior qualities of these materials. They would like to have personal protective equipment made with quality materials. The six farmers at Anyirawase who took part in the focus group discussion stated that they follow best practices in chemical application. They usually apply their chemicals in the mornings and late afternoons.

Another reason for not using appropriate protective clothing is that, they are expensive according to the farmers. All of them complained that putting on of nose and mouth guards for instance Journal of the Faculty of Agriculture and Veterinary Medicine, Imo State University Owerri website: www ajol.info; Attribution: Non-commercial CC BY-NC 
make them uncomfortable. This makes the case complicated as higher quality materials will mean higher prices than the current ones.

\section{Farmers' perception on effect of agro-chemicals on crops and the applicant}

When asked if the agro-chemicals have adverse effect on their crops, $100 \%$ of the response was no. "You will not destroy the crop if you apply the chemical well" was the response from one farmer and the rest in the group supported this at Avenui. Thus, all the forty farmers involved in the study believe that agro-chemicals do not have harmful effect on the targeted crop especially when the right chemical is applied. All of them, however, believe that the agro-chemicals have harmful effects on the applicant and attributed many ill health in their communities to them.

A farmer at Dzolo Gbogame stated that, agro-chemicals and farming activities weaken them making them looking older than their ages. The five other farmers in the group agreed on the statement. They said this leads to early death compared to those who do white colour jobs. It has been scientifically reported that the application of agro-chemicals can be fatal (Waggoner et al., 2013). Farmers claimed that they experience skin irritation after application of chemicals. This should not be taken for granted as some agro-chemicals are known to be contact dermatitis causing allergy and irritation (Spiewak 2001). In addition to the skin irritation mentioned at Dzolo, Saviefe farmers added headache and general body pains after farm operations. The farmers also mentioned chemicals that they suffer from most. For instance, at Holuta, farmers said that they suffer a lot of skin irritation after using Akate master on cocoa farms. Some farmers at Awudome Avenui also attributed sexual weaknesses to effect of agro chemicals.

\section{Perceived effect of agro-chemicals on the environment}

Apart from the applicants and the crops, agro-chemicals have adverse effect 'on other organisms in the environment. Scientific reports have indicated that agro-chemicals have adverse effect on fecundity of bees (Keulemans et al., 2019). The forty farmers in the study have this believe. The organisms of concern include non-target crops, animals and water bodies. Mostly affected organisms identified at Ho West District are cocoyam, mushrooms, honeybees and snails. They also mention the pollution of streams in the area.

There were some other interesting revelations from the study. Over dose of agro-chemicals is common as farmers want total control of weeds or insect pests. They over dose agro-chemicals because most are not as effective as advertised. They also over dose chemicals used for postharvest treatment of crops especially maize. Farmers at Saviefe Gbedome add fertilisers or cassava extracts to herbicides to make them more potent.

\section{CONCLUSION}

Farmers believe that farming would have been very difficult without agro-chemicals. However, they agree that the application of agro-chemicals is having side effect on themselves and the environment. They have noticed that some organisms like snails and cocoyam are getting lost. Journal of the Faculty of Agriculture and Veterinary Medicine, Imo State University Owerri website: www ajol.info; Attribution: Non-commercial CC BY-NC 
Their lands are also degrading because of the effect of agro-chemicals on soil micro-organisms. New weeds are also emerging as the result of their farming activities.

There are scientific evidence elsewhere supporting the symptoms farmers in the study complained of such as skin irritation and early death. Unfortunately, only $30 \%$ of the 40 farmers involved in the focus group discussion have had some training in the use of agro-chemicals. Urgent attention is needed to train not only these farmers but all farmers on best practices in the use of agro-chemicals for their own health and that of the environment. This is crucial as farming is the only source of livelihood for most famers and the fact that the agro-chemicals are important for their farming activities. The government and non-governmental organizations through the Ministry of Food and Agriculture (MoFA) have to come to the aid of farmers to train them on the use of agro-chemicals.

\section{Acknowledgement}

Mr. Godslove Agbale the Agricultural Extension Agent at Ho West Office of the Ministry of Food and Agriculture identified the farmers and arranged for the focus group discussion. The researchers express their appreciation for his support.

Funding: This study was funded by the researchers themselves, there was no external source of funding.

Conflict of Interest: The authors declare that they have no conflict of interest. 


\section{REFERENCES}

Aktar, M. W., Sengupta, D., and Chowdhury, A. (2009). Impact of pesticide use in agriculture: Their benefits and hazards. Interdisciplinary toxicology. 2(1), 1-12.

Ali, M. P., Bari M. N., Ahmed, N., Kabir M. M. M., Afrin, S., Zaman, M. A. U., Haque S. S., Willers, J. L., (2017). Rice production without insecticide in smallholder farmers' field. Frontiers in environmental sciences. https://doi.org/10.3389/fenvs.2017.00016

Aragon F. M., and Rud J. P. (2011). Mining, Pollution and agricultural productivity: evidence from Ghana. Retrieved 26 October, 2020, from https://www.researchgate.net/publication/254450492.

Bempah, C. K., and Donkor, A. K. (2011). Pesticide residues in fruits at the market level in Accra Metropolis, Ghana, a preliminary study. Environmental Monitoring and Assessment. 175 (1-4):551-561

Diao X., Hazell P., and Thurlow J. (2010). The role of agriculture in African development. World Development. 38(10):1375-1383. https://doi.org/10.1016/j.worlddev.2009.06.011

Dinham, B., (2003). Growing vegetables in developing countries for local urban populations and export markets: problems confronting small-scale producers. Pest Management Science. 59 (5): 575-582. https://doi.org/10.1002/ps.654

Fernie, A. R., and Yan, J. (2019). De Novo domestication: An alternative rout toward new crops for the future. Molecular plants. 12, 615-631. https://doi.org/10.1016/j.molp.2019.03.016

Franke A. C., Baijukya F., Kantengwa S., and Reckling M. (2019). Poor farmers - poor yields: Socio-economics, soil fertility and crop management indicators affecting climbing bean productivity in Northern Rwanda. Experimental agriculture. 55: 14 - 34 . https://doi.org/10.1017/S0014479716000028

Ghana Statistical Service (2014). 2010 Population and Housing Census, District Analytical Report, Ho West District.

Ghana Statistical Service (2010). Population \& Housing Census National, Analytical Report, GSS, Accra, Ghana.

Keulemans, W., Bylemans, D., and De Coninck, B. (2019). Farming without plant protection products. In-depth analysis, Panel for the Future of Science and Technology, EPRS, European Parliamentary Research Service Scientific Foresight Unit, PE 634.416. Brussels.

Kuranchie-Mensah, H. Atiemo, S. M. Palm, L. M. N. D., Blankson-Arthur, S., Tutu, A.O., and Fosu, P. (2012). Determination of organochlorine pesticide residue in sediment and water from the Densu river basin, Ghana. Chemosphere. 86(3):286-292. https://doi.org/10.1016/j.chemosphere.2011.10.031

Journal of the Faculty of Agriculture and Veterinary Medicine, Imo State University Owerri website: www ajol.info; Attribution: Non-commercial CC BY-NC 
Kwakye, M. O., Mengistie, B., Ofosu-Anim, J., Nuer, A. T. K, and Van den Brink, P.J. (2018). Pesticide Registration, Distribution and Use Practices in Ghana. Environment, Development and Sustainability.

Lema, E., Machunda, R., and Njau, K. N. (2014). Agro-chemicals use in horticulture industry in Tanzania and their potential impact to water resources. International Journal of Biological and Chemical Sciences. 8(2): 831-842.

Lobell, D. B., Cassman, K. G., and Field, C. B. (2009). Crop yield gaps: their importance, magnitudes and causes. Annual review of environment and resources. 34 doi: 10.1146/annurevfienviron.041008.093740

Macfadyen, S., Hardie, D. C., Fagan, L., Stefanova, K., Perry, K. D., Degraaf, H. E., Holloway, J., Spafford, H., Umina, P.A., (2014). Reducing insecticide use in broad acre grains

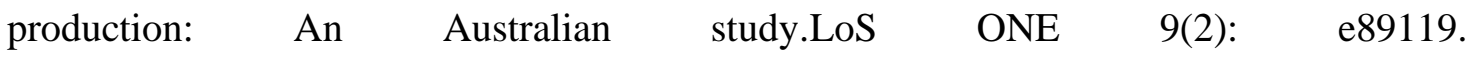
https://doi.org/10.1371/journal.pone.0089119

Mabe, F. N. Talabi, K., and Danso-Abbeam, G., (2017). Awareness of Health Implications of Agro-chemical Use: Effects on Maize Production in Ejura-Sekyedumase Municipality, Ghana. Advances in Agriculture.2017(2):1-11. doi.org/10.1155/2017/7960964

Ngowi, A. V. F. (2003). A study of farmers' knowledge, attitude and experience in the use of pesticides in coffee farming. African Newsletter on Occupational Health and Safety. 13: $62-64$

Northern Presbyterian Agricultural Services (2012). Ghana's Pesticide Crisis: The Need for Further Government Action. Northern Presbyterian Agricultural Services (NPAS), Tamale, Ghana, 2012

Ogg, C. L., Bauer, E. C., Hygnstrom, J. R., Bright, F. J., Puckett, G. J., and Alberts, C. A. (2018). Protective clothing and equipment for pesticides applicators. Nebraska extension.

Okoffo, E. D., Mensah, M., and Fosu-Mensah, B. Y. (2016). Pesticides exposure and the use of personal protective equipment by cocoa farmers in Ghana. Environmental Systems Research. 5(1): doi: 10.1186/s40068-016-0068-z

Omari, S. (2014). Assessing Farmers' knowledge of effects of agro-chemical use on human health and the environment: a case study of Akuapem South Municipality, Ghana. International Journal of Applied Sciences and Engineering Research. 3(2): 402-410.

Shrestha, A., Kurtural, S. K., Fidelibus, M. W., Dervishian, G., and Konduru, S. (2013). Efficacy and cost of cultivators, steam, or an organic herbicide for weed control on organic vineyards in the San Joaquin Valley of California. Horticultural Technology 23 (1) 99-108, doi: 10.21273/HORTTECH.23.1.99. 
Spiewak, R. (2001). Pesticides as cause of occupational skin diseases in farmers. Annals of agricultural and environmental medicine. 81(1): 1 - 5 .

Waggoner, J. K., Henneberger P. K., Kullman G. J., Umbach D. M., Kamel F., Freeman L. E.B. Alavanja, M. C. R., Sandler, D. P., and Hoppin, J. A. (2013). Pesticide use and fatal injury among farmers in the agricultural health study. International Archives of Occupational and Environmental Health. 86(2): 177-187. doi:10.1007/s00420-0120752-x. 


\section{APPENDIX}

Table 1: Farmer groups and their perception on effect of Agro-Chemicals

\begin{tabular}{|c|c|c|c|c|c|c|c|c|c|c|}
\hline 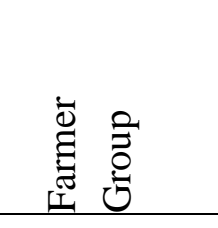 & 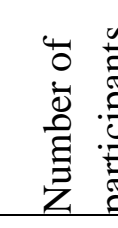 & 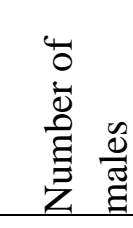 & 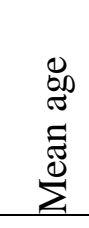 & 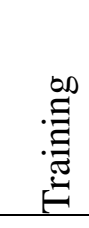 & o & 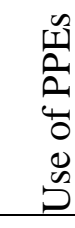 & 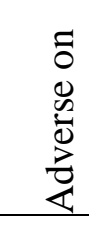 & ठิ) & 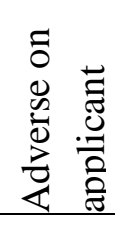 & 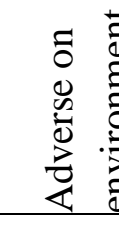 \\
\hline Dzolo & 6 & 5 & 55 & Yes & High & No & No & & Yes & Yes \\
\hline Saviefe & 6 & 5 & 48 & No & High & No & No & & Yes & Yes \\
\hline Holuta & 10 & 10 & 58 & No & High & No & No & & Yes & Yes \\
\hline Anyirawase & 6 & 5 & 52 & Yes & High & No & No & & Yes & Yes \\
\hline Avenui & 12 & 12 & 74 & No & High & No & No & & Yes & Yes \\
\hline
\end{tabular}

Note: 1. Training means having had training in the use of agro-chemicals 2. PPEs means personal protective equipment 